\title{
PERLINDUNGAN HUKUM TERHADAP HAK CIPTA MOTIF BATIK KUNINGAN BERDASARKAN UNDANG-UNDANG NOMOR 28 TAHUN 2014 TENTANG HAK CIPTA (Studi Kasus di Kabupaten Kuningan)
}

\author{
Siti Latifah, Anthon Fathanudien \\ Fakultas Hukum Universitas Kuningan, Kuningan, Indonesia \\ Email: slatifah881@gmail.com, anthonfathanudien@gmail.com
}

\begin{abstract}
Abstrak
Penelitian ini dilatarbelakangi oleh Undang-undang Hak Cipta Nomor 28 Tahun 2014 bahwa Indonesia adalah Negara kepulauan yang memiliki aneka ragam seni dan budaya yang sangat kaya. Hal tersebut disebabkan oleh adanya keanekaragaman suku bangsa, etnik, bahasa, tradisi dan agama yang secara keseluruhan merupakan potensi bangsa yang dilindungi.. Penelitian ini merupakan jenis penelitian yuridis empiris yang bersifat deskriptif analitis dengan pendekatan kualitatif. Jenis data yang digunakan adalah data primer, data sekunder dan data tersier. Teknik pengumpulan data dengan wawancara, observasi dan studi pustaka. Penelitian ini dilakukan di Desa Cikubangsari Kabupaten Kuningan. Hasil dari penelitian ini adalah berlakunya Undang-undang Nomor 28 Tahun 2014 tentang Hak cipta terkait perlindungan hukum dan pendaftaran Hak Cipta yang tercantum dalam Pasal 66 ayat (1) Undang-undang Nomor 28 Tahun 2014 Tentang Hak Cipta. Adapun pelaksanaan Undang-undang Nomor 28 Tahun 2014 Tentang Hak Cipta yaitu dari banyaknya motif batik Kuningan yang ada di Kuningan ternyata belum semuanya motif batik Kuningan didaftarkan dan hanya 10 motif dari 20 motif yang didaftarkan dengan jumlah keseluruhan 120 motif batik Kuningan yang dimiliki oleh pengrajin batik Kuningan yaitu yang berada di Desa Cikubangsari Kabupaten Kuningan sedangkan pemilik usaha batik di Kuningan belum mendaftarkan hak cipta motif batik Kuningan.
\end{abstract}

Kata kunci: Hak Cipta, Batik Kuningan, Perlindungan Hukum

\section{Abstract}

This research is motivated by the Copyright Law No. 28 of 2014 that Indonesia is an archipelagic country which has a very rich diversity of arts and culture. This is caused by the diversity of ethnic groups, ethnicities, languages, traditions and religions that as a whole are the potential of a protected nation. This research is an empirical juridical type of research that is analytical descriptive with a qualitative approach. The types of data used are primary data, secondary data and tertiary data. Data collection techniques by interviewing, observing and studying literature. This research was conducted in the Cikubangsari Village, Kuningan Regency. The results of this study are the enactment of Law Number 28 of 2014 concerning Copyright related to legal protection and registration of Copyright listed in Article 66 paragraph (1) of Law Number 28 of 2014 concerning Copyright. As for the implementation of Law No. 28 of 2014 concerning Copyright namely from the many Kuningan batik motifs in Kuningan it turns out that not all of the Kuningan batik motifs are registered and only 10 motifs from 20 motifs registered with a total of 120 Kuningan batik motifs owned by batik artisans Kuningan, which is located in the Cikubangsari Village, Kuningan Regency, while the batik business owner in Kuningan has not registered the Kuningan batik motif copyright.

Keywords: Copyright, Batik Kuningan, Legal Protection 


\section{A. PENDAHULUAN}

Indonesia merupakan negara kepulauan yang memiliki kekayaan yang melimpah, baik dari sumber daya alam maupun sumber daya manusia dan juga memiliki keanekaragaman seni dan budaya, salah satu seni yang terkenal dan diakui oleh dunia yaitu batik.

Batik merupakan salah satu warisan budaya Indonesia yang juga merupakan identitas bangsa. Ciptaan batik yang pada awal mulanya merupakan ciptaan khas bangsa Indonesia yang dibuat secara konvensional dilindungi oleh Undang-undang Hak Cipta Nomor 28 Tahun 2014 sebagai bentuk ciptaan tersendiri. Karya seperti itu memperoleh perlindungan karena mempunyai nilai seni, baik pada ciptaan motif atau gambar maupun komposisi warnanya ${ }^{1}$. Berbagai macam batik yang dapat dilihat dari segi warna dan corak gambar atau pola.

Batik dianggap sebagai hasil kerajinan asli yang diwariskan secara turun temurun, menurut sebagian besar masyarakat Indonesia. Batik berkaitan erat dengan aspek kehidupan sebagian besar masyarakat setempat. Motif yang terdapat dalam batik seringkali dikaitkan dengan berbagai simbol yang bermakna khusus dalam budaya mereka.

Motif batik Kuningan ini memiliki ciri khas yang berbeda dengan motif daerah lainnya. Motif batik ini merupakan simbol potensi yang sangat kental dengan budaya lokal masyarakat banyak yang mengenal bahkan memakainya serta bentuk yang sangat unik, yaitu desain batik yang mencerminkan ciri khas Kabupaten Kuningan seperti desain kuda dan ikan dewa.

Adapun bahan baku yang digunakan untuk pembuatan batik Kuningan adalah, Pertama, kain mori yang bermacam-macam jenisnya, dari yang berkualitas rendah sampai yang berkualitas tinggi. Kedua, malam atau lilin, bahan

${ }^{1}$ Tim Asian Law Group, Hak Kekayaan Intelektual Suatu Pengantar, PT. Alumni, Bandung, 2006, . 101 yang digunakan sebagai bahan tulis dari motif batik tulis dan bahan cap dan juga berfungsi untuk menghalangi warna agar tidak masuk ke serat kain. Ketiga, obat batik atau pewarna, digunakan untuk memberi warna pada kain yang sudah di batik atau di cap baik untuk warna dasar maupun warna tambahan dan ada berbagai jenis dari obat batik ini dari warnanya atau juga dari kualitasnya. Selain itu, ada juga bahan pembantu pembuatan batik yaitu soda kustik, tipol, minyak kacang, minyak kelapa, dan minyak tanah.

Selain bahan baku ada juga alat-alat yang digunakan untuk membuat batik Kuningan adalah, Pertama, canting, terdiri dari canting cap dan canting tulis yaitu digunakan untuk membuat gambar atau tulisan (membatik) setelah diisi lilin atau malam yang telah dipanaskan dan dicairkan dalam wajan. Kedua, Wajan, digunakan sebagai tempat lilin atau malam yang akan dicairkan. Ketiga, Kompor, merupakan tempat api (perapian) yang digunakan untuk memanaskan atau mencairkan lilin atau malam sehingga dapat digunakan untuk membatik cap atau tulis. Keempat, Gawangan, Tempat kain yang akan di batik dan alat ini biasanya terbuat dari bambu. Kelima, Meja Cap, alat ini digunakan untuk mengecap batik dan terbuat dari kayu yang diatasnya dialasi busa. Keenam, Drum, alat ini digunakan untuk merebus batik dengan tujuan pelepasan lilin atau malam, dan yang Ketujuh, Bak, alat untuk tempat mencuci.

Sedangkan proses pembuatan batik Kuningan yaitu dengan cara, yaitu, Pertama, kain dipotong-potong sesuai kebutuhan. Kedua, di ketel (proses untuk menghilangkan kanji yang menempel di kain). Ketiga, dilengreng atau digambar. Keempat, isen-isen atau mengisi gambar, Kelima, nembok atau dilepa. Keenam, proses pewarnaan. Ketujuh, dilorod atau direbus untuk melepaskan lilin, dan yang Kedelapan, dicuci kemudian dijemur.

Hak Kekayaan Intelektual (HKI) atau Intellectual Property Rights adalah hak hukum yang bersifat eksklusif 
(khusus) yang dimiliki oleh para pencipta sebagai hasil aktivitas intelektual dan kreativitas yang bersifat khas dan baru. Karya-karya intelektual dan kreativitas tersebut dapat berupa hasil karya cipta di bidang ilmu pengetahuan, seni dan sastra. Karya-karya di bidang Hak Kekayaan Intelektual dihasilkan berkat kemampuan intelektual manusia melalui pengorbanan tenaga, waktu, pikiran, perasaan dan hasil intuisi/ilham/hati nurani ${ }^{2}$. Adanya pengorbanan tersebut menjadikan karya yang dihasilkan memiliki nilai ekonomi karena manfaat yang dapat dinikmati berdasarkan konsep tersebut maka mendorong kebutuhan adanya penghargaan atas hasil karya yang telah dihasilkan berupa perlindungan hukum bagi Hak Kekayaan Intelektual. Tujuan pemberian perlindungan hukum ini untuk mendorong dan menumbuh kembangkan semangat berkarya dan mencipta ${ }^{3}$. Hak Kekayaan Intelektual merupakan suatu alat pembangunan ekonomi. Sistem perlindungan Hak Kekayaan Intelektual yang efektif akan memberikan stimulus atau rangsangan dalam pertumbuhan ekonomi suatu negara ${ }^{4}$.

\section{B. RUMUSAN MASALAH}

Berdasarkan latar belakang yang telah dipaparkan diatas, maka dapat dirumuskan dua masalah sebagai berikut : Pertama, bagaimana pengaturan perlindungan hukum terhadap Hak Cipta batik Kuningan berdasarkan Undangundang Nomor 28 Tahun 2014 Tentang Hak Cipta? Kedua, Bagaimana pelaksanaan perlindungan hukum terhadap

${ }^{2}$ Iswi Haryani, Prosedur Mengurus HAKI (Hak Atas Kekayaan Intelektual) Yang Benar Membahas Secara Runtut dan Detail Tentang Tata Cara Mengurus Hak Atas Kekayaan Intelektual, Pustaka Yustisia, Yogyakarta, 2010, . 16

${ }^{3}$ Afrillyanna, Trips-WTO dan Hukum HKI Indonesia Kajian Perlindungan Hak Cipta Seni BatikTradisional Indonesia, PT. Rineka Cipta, Jakarta, 2005, . 12

${ }^{4}$ Khoirul Hidayah, Hukum Hak Kekayaan Intelektual, Setara Press, Malang, 2017, . 8-9
Hak Cipta batik Kuningan berdasarkan Undang-undang Nomor 28 Tahun 2014 Tentang Hak Cipta?

\section{METODE PENELITIAN}

Dalam menganalisis rumusan permasalahan menggunakan penelitian yang bersifat kualitatif berdasarkan data yang diperoleh kemudian dikaitkan dengan peraturan perundang-undangan dan berdasarkan penelitian di lapangan, untuk menemukan kebenaran yang berdasarkan logika keilmuan hukum yang nantinya akan ditarik sebuah kesimpulan 5 .

Metode pendekatan yang dipergunakan dalam penelitian ini adalah yuridis empiris, yaitu penelitian yang didasarkan pada peraturan perundangundangan dan juga menggunakan penelitian yang didasarkan pada fakta, realita dan permasalahan yang ada di lapangan ${ }^{6}$. Yuridis empiris ini merupakan cara atau prosedur yang digunakan untuk memecahkan masalah penelitian dengan meneliti data sekunder terlebih dahulu untuk kemudian dilanjutkan dengan meneliti data primer yang ada di lapangan ${ }^{7}$. Jadi pendekatan yuridis empiris merupakan suatu penelitian yang meneliti peraturan hukum yaitu Undang-undang Nomor 28 Tahun 2014 Tentang Hak Cipta, yang kemudian dihubungkan dengan implementasi dari undang-undang tersebut, dan data ataupun perilaku yang hidup di tengah-tengah masayarakat Desa Cikubangsari Kabupaten Kuningan.

Adapun penelitian ini menggunakan sumber data primer, data sekunder dan data tersier. Data primer yaitu data yang diperoleh langsung dari sumbernya ${ }^{8}$. Data ini diperoleh dengan

${ }^{5}$ M. Kadir, Hukum dan Penelitian Hukum, PT. Citra Aditya Bakti, Bandung, 2004, . 176.

${ }^{6}$ Soerjono Soekanto, Pengantar Penelitian Hukum, Universitas Indonesia, Jakarta, 1986, . 46

7 Devi Rahayu, Perlindungan Hukum Terhadap Hak Cipta Motif Batik Tanjungbumi Madura, Mimbar Hukum, volume 23, Nomor 1, Februari 2011, . 118

${ }^{8}$ Iqbal Hasan, Metode Penelitian Hukum dan Aplikasinya,Remaja, Bandung, 1999, . 35 
wawancara secara langsung dengan pihak terkait yaitu pelaku usaha kerajinan batik Kuningan yang ada di Desa Cikubangsari selain itu juga ada dari Dinas Koperasi dan UKM serta dari Dinas Perdagangan dan Perindustrian Kabupaten Kuningan. Adapun data sekunder berupa bahan-bahan hukum seperti peraturan perundangundangan, buku, jurnal hukum dan lainlain yang terkait dengan masalah yang diteliti.

Lokasi penelitian adalah di Desa Cikubangsari Kabupaten Kuningan dengan dasar pertimbangan bahwa tempat tinggal informan kunci yaitu perajin batik, pelaku usaha batik dan pengusaha batik adalah pusat penghasil batik Kuningan. Penelitian ini dilakukan dengan cara mencari data secara langsung yang ada di Desa Cikubangsari untuk mengungkap fakta yang ada dan menggunakan informan kunci yang dipilih berdasarkan kriteria yang dianggap layak untuk memberikan keterangan.

Cara mengumpulkan datayaitu dengan mengumpulkan data hukum, kemudian diinventarisasi dan diklasifikasikan sesuai dengan permasalahan yang diangkat. Selain itu melakukan wawancara terstruktur yang merupakan proses tanya jawab dan menanyakan secara langsung informasiinformasi dari informan kunci dengan sistematik dan berlandaskan kepada tujuan penelitian. Wawancara dilakukan dengan menyiapkan pertanyaan-pertanyaan terlebih dahulu yang berkaitan dengan permasalahan tetapi dimungkinkan adanya variasi pertanyaan lainnya yang disesuaikan dengan situasi dan kondisi.

Adapun sebagai metode analisis data, pertama kali dilakukan editing yaitu memeriksa bahan dan data hukum untuk memastikan kelengkapan, kejelasan makna, korelasi dan relevansinya. Kedua, mengklasifikasikan hasil wawancara, literatur, dokumentasi, dan peraturan perundang-undangan. Analisis data penelitian menggunakan metode deskriptif analitis yaitu dengan menuturkan dan menggambarkan fakta apa adanya sesuai dengan permasalahan yang diteliti untuk mendapatkan pandangan-pandangan yang sesuai dengan temuan pustaka. Data kemudian dianalisis dengan UndangUndang Nomor 28 Tahun 2014 Tentang Hak Cipta dan ditampilkan secara deskriptif.

\section{PEMBAHASAN}

\section{Perlindungan Hukum Terhadap Hak Cipta Batik Kuningan Berdasarkan Undang-Undang Nomor 28 Tahun 2014 Tentang Hak Cipta}

Dalam Pasal 1 ayat 3 Undangundang Dasar Negara Republik Indonesia Tahun 1945 menyebutkan, bahwa "Negara Indonesia adalah Negara Hukum". Negara hukum dimaksud adalah Negara yang menegakkan supremasi hukum untuk menegakkan kebenaran dan keadilan dan tidak ada kekuasaan yang tidak di pertanggungjawabkan. Menurut Setiono, perlindungan hukum ${ }^{9}$ adalah tindakan atau upaya untuk melindungi masyarakat dari perbuatan sewenang-wenang oleh penguasa yang tidak sesuai dengan aturan hukum, untuk mewujudkan ketertiban dan ketentraman sehingga memungkinkan manusia untuk menikmati martabatnya sebagai manusia.

Adapun pengaturan perlindungan hukum terhadap Hak Cipta dalam Pasal 1 Undang-Undang Nomor 28 Tahun 2014 Hak Cipta adalah hak eksklusif pencipta yang timbul secara otomatis berdasarkan prinsip deklaratif setelah suatu ciptaan diwujudkan dalam bentuk nyata tanpa mengurangi pembatasan sesuai dengan ketentuan peraturan perundang-undangan. Hak cipta sebagaimana dimaksud dalam Pasal 4 merupakan hak eksklusif yang terdiri atas hak moral dan hak ekonomi serta di dalam Pasal 5 bagian kedua tentang hak moral yang tercantum dalam

9 Setiono, Rule Of Law (Supremasi Hukum), Magister Ilmu Hukum Program Pascasarjana Universitas Sebelas Maret, Surakarta, 2004, . 3 
Undang-undang No 28 Tahun 2014 Tentang Hak Cipta yaitu :

1) Hak moral sebagaimana dimaksud dalam Pasal 4 merupakan hak yang melekat secara abadi pada diri Pencipta untuk :

a. Tetap mencantumkan atau tidak mencantumkan namanya pada salinan sehubungan dengan pemakaian Ciptaannya untuk umum;

b. Menggunakan nama aliasnya atau samarannya;

c. Mengubah Ciptaannya sesuai dengan kepatutan dalam masyarakat;

d. Mengubah judul dan anak judul Ciptaan; dan

e. Mempertahankan haknya dalam hal terjadi distorsi Ciptaan, mutilasi Ciptaan, modifikasi Ciptaan, atau hal yang bersifat merugikan kehormatan diri atau reputasinya.

2) Hak moral sebagaimana dimaksud pada ayat (1) tidak dapat dialihkan selama Pencipta masih hidup, tetapi pelaksanaan hak tersebut dapat dialihkan dengan wasiat atau sebab lain sesuai dengan ketentuan peraturan perundang-undangan setelah Pencipta meninggal dunia.

3) Dalam hal terjadi pengalihan pelaksanaan hak moral sebagaimana dimaksud pada ayat (2), penerima dapat melepaskan atau menolak pelaksanaan haknya dengan syarat pelepasan atau penolakan pelaksanaan hak tersebut dinyatakan secara tertulis.

Jika dihubungkan antara penciptaan batik kuningan dengan bunyi pasal 1 angka (2) dan pendapat Copinger, maka dapat dideskripsikan bahwa batik Kuningan yang dibuat oleh pelaku usaha kerajinan batik, baik oleh perorangan maupun bersamasama merupakan salah satu bentuk ciptaan, dimana pelaku usaha kerajinan batik tersebut dinyatakan sebagai pencipta yang sekaligus memegang hak cipta hasil karya batik tersebut. Batik Kuningan merupakan karya cipta yang memerlukan keterampilan dan keahlian yang spesifik. Sebagai hasil karya intelektual, batik Kuningan mendapat perlindungan hukum sebagaimana diatur dalam Undang-undang Nomor 28 Tahun 2014 Tentang Hak Cipta. Menurut copinger menyatakan bahwa yang dimaksud dengan pencipta adalah ....the "author" of the work is to be the first owner of the copyright there in. (pencipta dari suatu ciptaan merupakan pemilik pertama dari ciptaan itu sendiri) ${ }^{10}$.

Seni batik dalam Undang-undang Hak Cipta dikategorikan sebagai seni atau artistic work. Pada pasal 58 ayat (1) Undang-undang Hak Cipta Nomor 28 Tahun 2014 menyatakan bahwa:

a. Perlindungan hak cipta atas ciptaan

1) Buku, pamflet, dan semua hasil karya tulis lainnya;

2) Ceramah, kuliah, pidato, dan ciptaan sejenis lainnya;

3) Alat peraga yang dibuat untuk kepentingan pendidikan dan ilmu pengetahuan;

4) Lagu atau musik dengan atau tanpa teks;

5) Drama, drama musikal, tari, koreografi, pewayangan,dan pantomim;

6) Karya seni rupa dalam segala bentuk seperti lukisan, gambar, ukiran, kaligrali, seni pahat, patung, atau kolase;

7) Karya arsitektur;

8) Peta; dan

9) Karya seni batik atau seni motif lain. Perlindungan hukum mengenai Hak Cipta motif batik yang tercantum dalam Pasal 58 ayat (1) Undang-undang Nomor 28 Tahun 2014 tentang Hak Cipta adalah suatu motif batik yang memenuhi unsur orisinal, maksudnya pencipta sendiri yang menciptakan sendiri motif tersebut walaupun dirinya terinspirasi dengan sesuatu hal yang sudah ada. Berdasarkan Pasal 1 angka 3 Undang-undang Nomor 28 Tahun 2014 tentang Hak Cipta dikatakan bahwa ciptaan adalah hasil setiap karya Pencipta yang menunjukan keasliannya dalam lapangan ilmu pengetahuan, seni

${ }^{10}$ Eddy Damian, Hukum Hak Cipta, Alumni, Bandung, 2002, . 40 
dan sastra. Berdasarkan Pasal tersebut, hak cipta hanya melindungi karya-karya asli tetapi tidak mensyaratkan karya tersebut harus bersifat kreatif. Ciptaan itu termasuk asli apabila ciptaan tersebut bukan merupakan jiplakan atau tiruan dari ciptaan lain $^{11}$. Namun berdasarkan penjelasan umum Undang-undang Nomor 28 Tahun 2014 tentang Hak Cipta, ciptaan yang dilindungi adalah ciptaan yang memiliki bentuk yang khas, bersifat pribadi dan menunjukan keaslian sebagai ciptaan yang lahir berdasarkan kemampuan, kreativitas atau keahlian sehingga dapat dilihat, dibaca atau didengar.

Pemahaman terhadap penerapan Undang-undang Nomor 28 Tahun 2014 tentang Hak Cipta dapat mengakomodir kepentingan pelaku usaha kerajinan batik dari berbagai pihak. Dengan adanya Undang-undang Nomor 28 Tahun 2014 tentang Hak Cipta dan diterapkan secara benar dengan dilengkapi oleh sarana dan prasarana serta aparat yang handal, memang akan banyak memberi keuntungan bagi pelaku usaha kerajinan batik atau pencipta motif/corak batik. Penerapan Undang-undang Nomor 28 Tahun 2014 tentang Hak Cipta yang dilakukan sesuai dengan aturan hukum yang benar serta dilandasi dengan kesadaran masyarakat pelaku usaha kerajinan batik yang mau menghargai karya cipta batik pelaku usaha kerajinan batik serta menghilangkan tradisi menganggap bahwa karya cipta batik adalah peninggalan leluhur maka penerapan Undang-undang Nomor 28 Tahun 2014 tentang Hak Cipta dapat mengakomodir kepentingan pelaku usaha kerajinan batik $^{12}$.

\section{Pelaksanaan Perlindungan Hukum} Terhadap Hak Cipta Batik Kuningan

11 Tim Lindsey dkk, Hak Kekayaan Intelektual Suatu Pengantar, cetakan ke-5, PT. Alumni, Bandung, 2006, . 106

${ }^{12}$ Setyawati, Penerapan Undang-undang Hak Cipta dalam Rangka Perlindungan Hukum Karya Perajin Batik Surakarta, http://eprints.undip.ac.id/1303/, diakses 2 juni 2010

\section{Berdasarkan Undaang-Undang Nomor 28 Tahun 2014 Tentang Hak Cipta}

Perlindungan hak cipta motif batik dilindungi oleh hukum ketika terwujud atau diekspresikan, sehingga pencipta atau pemegang cipta suatu motif batik tidak diharuskan melakukan pendaftaran ke Direktorat Jenderal Hak Kekayaan Intelektual. Jadi tanpa didaftarkan pun hak cipta atas karya seni batik yang diciptakan atau diwujudkan otomatis mendapat perlindungan hukum hak cipta. Pendaftaran hak cipta juga bukan merupakan suatu pengesahan. Namun, fungsi pendaftaran hanyalah sebagai alat pembuktian atau bukti awal bahwa pencipta berhak atas hak cipta. Manfaat pencipta mendaftarkan ciptaannya, yaitu pendaftar dianggap sebagai pencipta, sampai ada pihak lain yang dapat membuktikan tsebaliknya di pengadilan. Pendaftar menikmati perlindungan hukum sampai adanya putusan hakim yang berkekuatan hukum tetap menyatakan pihak lain yang menjadi penciptanya ${ }^{13}$. Untuk memperoleh pencatatan ciptaan di Kementerian Hukum dan Hak Asasi Manusia di Indonesia permohonan dapat melakukan pengajuan permohonan melalui tiga alternatif, yaitu: ${ }^{14}$

1) Melalui Direktorat Jenderal Hak Kekayaan Intelektual (Ditjen HKI);

2) Melalui Kantor Wilayah Kementerian Hukum Dan Hak Asasi Manusia Republik Indonesia di Seluruh Indonesia; dan

3) Melalui kuasa hukum konsultan Hak Kekayaan Intelektual yang terdaftar di Kementerian Hukum Dan Hak Asasi Manusia Republik Indonesia di Seluruh Indonesia .

13 Budi Agus Riswandi, Budi \& $\mathrm{M}$. Syamsudin, Hak Kekayaan Intelektual \& Budaya Hukum, Rajagrafindo Persada, 2005, . 19

14 Tim Visi Yustisia, Panduan Resmi Hak Cipta Dari Mulai Mendaftar, Melindungi, Hingga Menyelesaikan Sengketa, Visimedia, Jakarta Selatan, 2015, , 20. 
Sistem pendaftaran hak cipta berdasarkan Undang-undang Nomor 28 Tahun 2014 tentang Hak Cipta yang bersifat deklaratif artinya pendaftaran bukan merupakan suatu keharusan. Menurut Rachmadi Usman menyatakan bahwa pendaftaran hanya untuk pembuktian, bukan untuk menerbitkan hak melainkan hanya memberikan dugaan atau sangkaan hukum atau presumption iuris yaitu pihak yang haknya terdaftar adalah pihak yang berhak atas hak tersebut dan sebagai pemakai pertama atas hak yang didaftarkan ${ }^{15}$.

Berdasarkan sistem tersebut di atas, maka pendaftaran karya seni batik bukan merupakan suatu keharusan bagi pencipta atau pemegang hak cipta, suatu karya cipta dicatatkan atau tidak tetap mendapatkan perlindungan hak cipta, namun pernyataan tersebut akan menjadi suatu hal yang kontradiksi ketika ada pencipta motif batik yang tidak mencatatkan ciptaan motif batiknya, kemudian terjadi konflik sengketa, dan pencipta tersebut kalah di pengadilan karena tidak bisa membuktikan karya motif batiknya adalah ciptaannya. Padahal memang benar adalah ciptaannya. Apabila hal itu terjadi, maka sama saja tidak ada perlindungan hak cipta ketika suatu karya tidak dicatatkan.

Tata cara perolehan hak cipta pada prinsipnya dapat diperoleh ketika ciptaan tersebut diwujudkan. Hal ini berbeda dengan karya intelektual lain yang mensyaratkan dalam perolehan haknya melalui proses pendaftaran. Akan tetapi, dalam pengertian ini ciptaan tidak dapat didaftarkan. Pada dasarnya ciptaan dapat didaftarkan. Namun, fungsi pendaftaran hanyalah sebagai alat pembuktian bahwa pencipta berhak atas hak cipta. Di samping itu, pendaftaran ini akan memberikan manfaat bagi si pendaftar. Manfaatnya pendaftar dianggap sebagai pencipta, sampai ada pihak lain yang dapat membuktikan sebaliknya di Pengadilan.

15 Rachmadi Usman, Hukum Atas Hak Kekayaan Intelektual, PT Alumni Bandung, 2003, 23.
Pendaftar menikmati perlindungan hukum sampai adanya putusan hakim yang berkekuatan hukum tetap yang menyatakan bahwa pihak lain (bukan pendaftar) yang menjadi pencipta ${ }^{16}$. Untuk jelasnya prosedur pendaftaran hak cipta sebagai berikut :

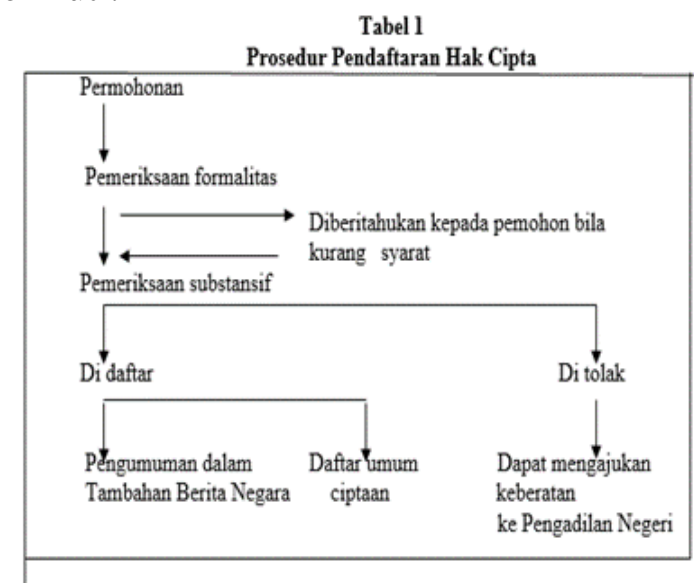

Sumber : Kantor Dinas Perindustrian dan Perdagangan

Dalam bagan di atas terlihat bagaimana prosedur pendaftaran hak cipta begitu rumitnya, yaitu dengan tahapantahapan sebagai berikut, pemohon dapat mengajukan motif batik Kuningan yang akan didaftarkan setelah itu motif tersebut diperiksa oleh Direktorat Jenderal Hak Kekayaan Intelektual dengan cara pemeriksaan formalitas, yaitu syarat-syarat pemohon mengajukan motif batik Kuningan terdapat kekurangan maka pihak Direktorat Jenderal Hak Kekayaan Intelektual akan memberitahukannya kepada pemohon. Setelah syarat-syarat sudah lengkap maka tahap berikutnya adalah tahapan pemeriksaan substansif yang merupakan didaftarkan atau ditolaknya motif batik Kuningan karena proses untuk mendaftarkan motif batik Kuningan tersebut mengacu pada 21 (dua puluh satu) jenis uji Standar Nasional Indonesia (SNI) yang terdiri dari uji batik rayon, batik sutera, ukuran produk batik, ciri kain batik tulis, ciri batik tulis, ciri

16 Sanusi Bintang dan Dahlan, Pokokpokok Hukum Ekonomi dan Bisnis, Citra Aditya Bakti, Bandung, 2000, 88 
batik cap, cara uji batik cap, cara uji batik kombinasi dan lain sebagainya. Dari pemeriksaan substansif, motif batik Kuningan lulus dari uji batik tersebut maka motif batik Kuningan bisa langsung didaftarkan dan dapat dilihat dalam pengumuman dalam Tambahan Berita Negara. Sedangkan kalau yang di tolak dalam uji batik maka pemohon dapat mengajukan keberatan ke Pengadilan Negeri.

Pada umumnya pelaku usaha kerajinan batik Kuningan berpendapat bahwa pendaftaran karya cipta motif batik yang ada di Desa Cikubangsari Kabupaten Kuningan bukan merupakan hal yang mendesak. Umumnya mereka mempersoalkan mahalnya biaya pendaftaran, waktunya lama, dan prosesnya berbelit-belit. Selain itu, pendaftaran yang dilakukan tetap tidak mampu mencegah terjadinya praktik peniruan atau penjiplakan terhadap karya cipta motif batik Kuningan yang telah didaftar. Upaya pelarangan akan mengalami kesulitan apabila peniruan atau penjiplakan motif batik yang telah didaftar itu dilakukan oleh pengusaha batik batik yang tergolong kecil.

Bagi pengusaha batik yang tergolong menengah ke bawah, masih jarang yang mendaftarkan karya motif batiknya. Ada beberapa alasan yang dikemukakan antara lain yaitu motivasi untuk mendaftarkan hak cipta masih rendah. Hal ini disebabkan karena pelaku usaha kerajinan batik akan menganggap penting apabila produknya laku terjual dan belum memikirkan pentingnya kegunaan hak cipta bagi produk yang dihasilkan.

Berdasarkan hasil penelitian dan hasil dari wawancara pelaku usaha kerajinan batik Kuningan bahwa menganggap penting pencatatan ciptaan sebagai perlindungan terhadap hasil karya pencipta agar tidak di jiplak maupun di klaim oleh pihak lain. Walaupun pencatatan hak cipta dianggap penting. Namun pada prakteknya tidak semua mencatatkan ciptaannya karena berbagai alasan.

Tabel 2

Daftar Batik-batik Kuningan

\begin{tabular}{|c|l|l|l|}
\hline No. & Nama & $\begin{array}{l}\text { Sudah } \\
\text { didaftarkan }\end{array}$ & $\begin{array}{l}\text { Belum } \\
\text { didaftarkan }\end{array}$ \\
\hline 1 & $\begin{array}{l}\text { Batik } \\
\text { Cikubangsari }\end{array}$ & 10 motif & 120 motif \\
\hline 2 & Batik Bojong & & Belum \\
\hline 3 & $\begin{array}{l}\text { Lingga } \\
\text { Mekar }\end{array}$ & Belum \\
\hline 4 & $\begin{array}{l}\text { Paseban } \\
\text { Cigugur }\end{array}$ & & Belum \\
\hline 5 & Nauan & & Belum \\
\hline 6 & $\begin{array}{l}\text { Batik Dakor } \\
\text { Jalaksana }\end{array}$ & & Belum \\
\hline
\end{tabular}

Dari uraian diatas bisa dilihat hanya baru satu yang sudah di daftarkan Hak Ciptanya yaitu hanya batik Cikubangsari yang telah mendaptarkan motif batiknya dan masih kebanyakan belum di daftarkan karena ada faktor yang menyebabkan pencipta maupun pelaku usaha kerajinan batik Kuningan belum melakukan pendaftaran hak cipta motif karena lamanya waktu pendaftaran ${ }^{17}$.

Berdasarkan hasil penelitian di lapangan ada beberapa hal dalam permasalahan-permasalahan pendaftaran Hak Cipta motif batik Kuningan dari sisi pelaku usaha kerajinan batik yaitu yang pertama, kurangnya kesadaran hukum dan pemahaman pelaku usaha kerajinan batik tentang hak cipta, kedua, biaya pencatatan ciptaan kurang terjangkau bagi pelaku usaha kerajinan batik, ketiga, rumit dan prosesnya lama; sedangkan dilihat dari sisi pemerintah yaitu yang pertama, minimnya anggaran dan kuota fasilitasi pencatatan ciptaan yang ditanggung oleh pemerintah terbatas, kedua, kurangnya Sumber Daya Manusia (SDM) untuk melakukan sosialisasi terkait hak kekayaan intelektual dan program pencatatan ciptaan.

Selain permasalahan yang di atas ada juga solusi yang dapat dilakukan oleh pemerintah dan pelaku usaha kerajinan yaitu di lihat dari segi pemerintah, yang

17 Wawancara Dengan Pelaku Usaha Kerajinan Batik Kuningan di Desa Cikubangsari Kuningan 
pertama, menambah anggaran dan menambah kuota fasilitasi pencatatan ciptaan secara gratis, kedua, melakukan sosialisasi secara langsung terkait hak kekayaan intelektual dan program pencatatan ciptaan, ketiga, mempercepat proses pencatatan ciptaan, keempat, membentuk tim advokasi/pendamping UMKM khusus bagian hukum dan hak kekayaan intelektual di kawasan industri batik Kuningan. Sedangkan dilihat dari segi pelaku usaha kerajinan batik yaitu pertama, meningkatkan kesadaran hukum secara mandiri untuk lebih peduli terhadap perlindungan hukum hak cipta, kedua, mengenal tentang pengaturan yang terkait dengan hak cipta, karena dengan mengenal pengaturan yang terkait dengan hak cipta diharapkan para pelaku usaha kerajinan batik lebih memahami dan peduli terhadap hak cipta atas ciptaan motif batiknya.

\section{KESIMPULAN}

1. Bahwa perlindungan hukum terhadap hak cipta motif batik secara umum telah ada dalam Undang-undang Nomor 28 Tahun 2014 tentang hak cipta. Berdasarkan perkembangan, motif batik yang mendapat perlindungan hak cipta adalah motif yang bukan tradisional dengan pertimbangan bahwa motif batik yang tradisional telah menjadi milik bersama (public domain). Perlindungan hukum terhadap hak cipta motif batik diperoleh secara otomatis tanpa pendaftaran. Pendaftaran hak cipta motif batik Kuningan masih jarang dilakukan. Motif batik Kuningan tersebut dilindungi karena mempunyai nilai seni, baik dalam kaitannya dengan gambar, corak maupun komposisi warana. Undang-undang Nomor 28 Tahun 2014 tentang hak cipta juga menegaskan bahwa pentingnya melindungi Hak cipta dikarenakan setiap pencipta, yang dalam hal ini adalah pencipta motif batik kontemporer berhak atas hak moral dan hak ekonomi.
2. Pada saat ini hanya baru satu batik motif kuningan yaitu batik yang ada di Desa Cikubangsari Kabupaten Kuningan yang sudah didaftarkan hak ciptanya yaitu dengan 10 motif yang sudah terdaftar dari 20 motif yang di daftarkan dari jumlah 120 motif dan beberapa batik kuningan belum sepenuhnya mendaftarkan hak cipta motif batik tersebut Namun upaya pmerintah dalam melindungi hak cipta batik Kuningan bukan hanya membantu pendaftaran tetapi pelatihan dan peralatan di bantu oleh pemerintah, pemerintah saja sangat respon sekali kepada batik kuningan ini serta dukungan yang diberikan.

\section{SARAN}

1. Perlu adanya sosialisasi peraturan perundang-undangan yaitu Undangundang Nomor 28 Tahun 2014 Tentang Hak Cipta, pemerintah perlu melakukan langkah-langkah strategis agar pelaku usaha kerajinan batik Kuningan dapat mendaftarkan hak cipta motif batik Kuningan dalam melindungi ciptaan batiknya sendiri dan diharapkan kepada Dinas Perdagangan dan Perindustrian serta Dinas Koperasi dan Usaha Kecil Menengah Kabupaten Kuningan untuk memberikan pengetahuan dan pembinaan kepada pelaku usaha kerajinan batik Kuningan mengenai pentingnya mengenai Hak cipta motif batik Kuningan agar mendapatkan perlindungan hak kekayaan intelektual serta dalam hal teknis, perlu adanya peraturan pelaksana yang mengatur lebih rinci tentang masalah hak cipta yang dalam hal ini Pemerintah Daerah Kabupaten Kuningan harus membuat suatu peraturan daerah mengenai hak cipta maupun bidang Hak Kekayaan Intelektual lainnya.

2. Perlu adanya kesadaran hukum bagi para pelaku usaha kerajinan batik untuk melindungi ciptaaan baru hasil kreativitasnya sendiri, sehingga motif batik yang ada di Indonesia menjadi 
bertambah dan juga diharapkan adanya rasa saling menghargai antara pelaku usaha kerajinan batik dengan pelaku usaha kerajinan batik lainnya terhadap motif batik Kuningan dan juga perlu untuk meminta dan mendapat izin dari pencipta motif batik jika ingin meniru motif batik milik pelaku usaha kerajinan batik lain. Selain itu, para pelaku usaha kerajinan batik harus memahami hukum tentang hak cipta untuk lebih melindungi hasil dari ciptaannya tersebut.

\section{DAFTAR PUSTAKA}

Afrillyanna, Trips-WTO dan Hukum HKI Indonesia Kajian Perlindungan Hak Cipta Seni BatikTradisional Indonesia, PT. Rineka Cipta, Jakarta, 2005.

Budi Agus Riswandi, Budi \& M. Syamsudin, Hak Kekayaan Intelektual \& Budaya Hukum, Rajagrafindo Persada, 2005

Devi Rahayu, Perlindungan Hukum Terhadap Hak Cipta Motif Batik Tanjungbumi Madura, Mimbar Hukum, volume 23, Nomor 1, Februari 2011

Eddy Damian, Hukum Hak Cipta, Alumni, Bandung, 2002

Iswi Haryani, Prosedur Mengurus HAKI (Hak Atas Kekayaan Intelektual) Yang Benar Membahas Secara Runtut dan Detail Tentang Tata Cara Mengurus Hak Atas Kekayaan Intelektual, Pustaka Yustisia, Yogyakarta, 2010

Iqbal Hasan, Metode Penelitian Hukum dan Aplikasinya,Remaja, Bandung, 2002

Khoirul Hidayah, Hukum Hak Kekayaan Intelektual, Setara Press, Malang, 2017 M. Kadir, Hukum dan Penelitian Hukum, PT. Citra Aditya Bakti, Bandung, 2004

Rachmadi Usman, Hukum Atas Hak Kekayaan Intelektual, PT Alumni Bandung, 2003

Sanusi Bintang dan Dahlan, Pokok-pokok Hukum Ekonomi dan Bisnis, Citra Aditya Bakti, Bandung, 2000
Setiono, Rule Of Law (Supremasi Hukum), Magister Ilmu Hukum Program Pascasarjana Universitas Sebelas Maret, Surakarta, 2004

Setyawati, Penerapan Undang-undang Hak Cipta dalam Rangka Perlindungan Hukum Karya Perajin Batik Surakarta, http://eprints.undip.ac.id/1303/, diakses 2 juni 2010

Soerjono Soekanto, Pengantar Penelitian Hukum, Universitas Indonesia, Jakarta, 2010

Tim Asian Law Group, Hak Kekayaan Intelektual Suatu Pengantar, PT. Alumni, Bandung, 2006

Tim Lindsey dkk, Hak Kekayaan Intelektual Suatu Pengantar, cetakan ke-5, PT. Alumni, Bandung, 2006

Tim Visi Yustisia, Panduan Resmi Hak Cipta Dari Mulai Mendaftar, Melindungi, Hingga Menyelesaikan Sengketa, Visimedia, Jakarta Selatan, 2015 